\title{
Correlation of Organizational Culture with Company Innovation
}

\author{
Miftahul Rahmat Rauf ${ }^{1}$, Haedar Akib², Muh. Rizal ${ }^{3}$ \\ 1,2,3 Program Studi Ilmu Administrasi Bisnis, Fakultas Ilmu Sosial, Universitas Negeri Makassar \\ Email: miftahulrahmat@gmail.com ${ }^{1}$
}

(Received: 28 July 2020; revised: 14 August 2020; published: 23 September 2020)

\begin{abstract}
Organizational Culture is an important component in organization. This research discussed the correlation of organizational culture with company innovation in Perum Bulog Sulselbar Regional Divisions. This type of research is a descriptive research using a quantitative study design. Data collected techniques are carried out through observation, questionnaires and documentation. In this study, researchers tried to ascertain whether organizational culture has a relationship with company innovation. This research using a survey method. The data was collected by a questionnaire and analyzed using a statistical formula, with Spearman Rank Correlation which is calculated using SPSS. Based on data processing for the organizational culture variable, it was obtained a value of 82 percent, so it concluded that the organizational culture, was in the very good category. For the company's innovation variable obtained a value of 86 percent, so it concluded that the innovation is in the very good category. The results of this study are that there is a relationship between organizational culture with company innovation, with a high correlation coefficient score up to $=0,705$, So it can be concluded that organizational culture is correlated with a high level of correlation with company innovation at the general company Bulog, the Regional Division of South Sulawesi in Makassar.
\end{abstract}

Keywords: Competence, Discipline, Motivation, Job Satisfaction and Employee Performance.

Copyright $\odot 2020$ Universitas Negeri Makassar. This is an open access article under the CC BY license (http://creativecommons.org/licenses/by/4.0/)

\section{INTRODUCTION}

Organization is a consciously coordinated social unit with a relatively identifiable limit, working on a relatively continuous basis to achieve a common goal or a group of goals (Cholliq, 2016) argues that an organization is actually a collection of people who are integrated in a cooperation forum to ensure the achievement of the stated goals. The organization will be able to run well and smoothly if there is cooperation between fellow members, leaders and administrators of the organization, this collaboration is created and fostered by all parties, especially the leadership of the organization as a determinant of existing policies. Building an organizational culture is about opening minds and winning people's hearts to new ways of 
working, and about improving relationships between people and giving each employee meaning and satisfaction at work through a sense of belonging and shared values.

Organizational culture according to (Wibowo, 2016) refers to a system of shared meanings adopted by the members that differentiate the organization from other organizations. Therefore organizational culture will determine what members in the organization can and cannot do, such as determining normative boundaries for organizational members' behavior, determining acceptable managerial styles for members of the organization, determining appropriate work methods in the process organization and so on. According to (Akib, 2017) Human resources are an asset that must be constantly considered to have good organizational performance, so that it can develop the organization in the various demands of society. According to (Robbins \& Judge, 2015) There are seven indicators that can capture the essence of organizational culture, namely: courage to take risks, attention to details, orientation to results, orientation to people, orientation to the team, aggressiveness, stability.

Company Innovations according to (Lamsihar \& Huseini, 2019) is an idea, idea or an action to create something that is considered new by someone to answer a common problem. In this discussion, innovation can be said to be something that is really new on the basis of the thoughts or views of people saying that these ideas or actions are new. Innovation is something that is new towards improvement, which is different from before and is done intentionally and planned or not by accident, this is in accordance with the income raised by (Robbins \& Judge, 2015), that innovation is a new idea that is applied to initiate or improve a product, process or service. According to (Szczepanska, 2014) the company's key innovation is the development of support and encouragement for each employee to seek and find new ways of achieving the objectives and performing the task.

Large companies give employees the right to express their opinions, propose new ideas regardless of their position in the company and the freedom to question the policies of managers. According to (Hamell \& Prahald, 2002) Innovation indicators include two things, the first is productivity or making improvements and technical changes in a production process, productivity aims to provide more goods or services using less resources and still maintain high quality. Then the second is efficiency, which is an effort to achieve the maximum possible target by using the available resources in a relatively short time.

Based on the description of the importance of organizational culture and company innovation, the researchers determined the object of research at the Sulsebar Regional Division of Public Corporation in Makassar, which is one of the State-Owned Enterprises, which carries out activities to maintain the basic purchase price for unhulled rice, stabilize prices, especially the basic price, distribute rice to poor people (Raskin) and food stock management. Perum Bulog implements an organizational culture that encourages the quality of its employees, starting from hiring employees who use third parties so as to minimize fraud by certain parties in the company to giving responsibility, workload and fair rewards to each employee. The same opportunity is also given to every employee to take part in basic training programs and further education as an effort to improve employee quality.

Improving the quality of employees carried out by forming a good organizational culture will have a positive impact on company performance because employees of the company are the 
Miftahul Rahmat et.all; Correlation of Organizational... |71

ones who understand the work process and the challenges faced by the company so that it can trigger innovations or improvements in various areas of the company. The purpose of this study was to examine the relationship and to determine the high level of relationship in the organizational culture variables with company innovation at Perum Bulog Sulselbar Regional Division in Makassar.

\section{METHOD}

The design used in this research is quantitative research, which is to test hypotheses in accordance with the formulation of the problem under study so that it can be seen whether or not there is a significant correlation between cultural relations and company innovation at Perum Bulog Sulselbar Regional Division in Makassar. The population that became the target of this study were 60 employees at Perum Bulog, Regional Division of South Sulawesi in Makassar. While determining the sample using the population method, which according to (Sugiyono, 2010), that if the population is less than 100, it can be used as the total number of samples in this study, so that the number of samples is determined to be 60 people. The type of data used in this research is quantitative data, which is data obtained from the Regional Office of Bulog, South Sulawesi Regional Division in Makassar in the form of a questionnaire and reanalyzed. While the data sources used are primary data and secondary data. Primary data, namely data obtained from respondents' responses to the question items raised in the questionnaire. Secondary data, namely data obtained from documents and archives at the Perum Bulog Regional Division of Sulselbar in Makassar which are related to this research. The technique of collecting data is by means of field research and library research. Field research, searching for and obtaining data from Perum Bulog, Regional Division of Sulselbar in Makassar and employees as respondents who were researched researchers. The method used is observation, questionnaire. Observation, Conducting direct observation and studying matters related to direct research at Perum Bulog Sulselbar Regional Division in Makassar. Questionnaire. Asking questions that have been prepared in writing by distributing questionnaires and accompanied by alternative answers that will be given to respondents. Literature Research, Obtaining data by reading and studying books that are related in the field of human resource management related to the object of research.

\section{RESEARCH RESULTS AND DISCUSSION}

Respondents' response data regarding Organizational Culture at Perum Bulog Regional Division of Sulselbar in Makassar, then for the first indicator, namely the courage to take risks, the average respondent gave agreed answers, namely 40 people (66.7\%), the second indicator was the extent to which employees were expected to carry out precision, analysis, and attention to details, most respondents gave agreed answers, namely as many as 37 people $(61.7 \%)$, the third indicator explains the extent to which management focuses more on results than on the techniques and processes used to achieve these results, dominated by answers, most respondents agreed, namely as many as 32 people $(53.3 \%)$. Then the fourth indicator explains the extent to which management decisions take into account the effect of these results on people in the organization, most respondents' answers are agreeing with the number of respondents as many as 34 people (56.7\%), while the fifth indicator explains the extent of work activities. organized 
in teams rather than individuals, the average respondent gave an answer that strongly agreed with the number of respondents as many as 29 people (48.3\%), the sixth indicator explains the extent to which company employees are aggressive and competitive rather than relaxed, the average respondent gives answers agree that as many as 34 people $(56.7 \%)$. The seventh indicator is about the extent to which organizational activities emphasize maintaining the state of the company with its comparison to the company's growth. It appears that most of the respondents agreed, namely as many as 33 people $(55.0 \%)$.

In the responses of respondents regarding Corporate Innovation at Perum Bulog, Regional Division of Sulselbar in Makassar, the first indicator is the ability possessed by employees as a driving force in operational activities within the company both in terms of quality and quantity for the success of the company, on average the respondents gave an agreed answer. Namely as many as 32 people $(53.3 \%)$. This indicator shows that employees are professional and have the principle that everyone is a driving force in the company's operational activities so that every employee always prioritizes work quantity and quality. The second indicator is that the performance of an organization in optimizing the use of limited resources to get maximum results, most of the respondents gave very agreeable answers, namely as many as 33 people $(55.1 \%)$, this indicator shows that employees have the integrity to achieve the maximum possible target. doing the task using the resource that is drinkable as possible.Hasil penelitian ini menunjukkan bahwa hasil analisis koefisien korelasi untuk budaya organisasi dengan inovasi perusahaan sebesar 0,705 , sehingga dapat disimpulkan bahwa budaya organisasi memiliki korelasi tinggi dan signifikan terhadap inovasi perusahaan pada Perum Bulog Divisi Regional Sulselbar di Makassar.

To analyze organizational culture at Perum Bulog Regional Division of Sulselbar in Makassar, the organizational culture theory is used (Robbins \& Judge, 2015) which suggests aspects of organizational culture, namely: courage to take risks, attention to detail, orientation to results, orientation to people, orientation. On the team, aggressiveness and stability. In general, the organizational culture at the Perum Bulog Regional Division of Sulselbar in Makassar is in the very good category with a percentage rate of 82 percent. From all the percentage level results in the seven indicators contained in the organizational culture variable, it was found that the organizational culture at Perum Bulog, Regional Division of Sulselbar in Makassar was in the very good category. This is also supported by the documentation of the annual report of Perum Bulog which shows the results of the assessment of corporate governance carried out at Perum Bulog where in the last 5 years they have obtained very good qualifications.

Company innovation is a planned change in ideas and ideas in creating products, processes and services. Innovation is also defined as something new towards improvement. According to (Lamsihar \& Huseini, 2019) argues that innovation is an idea, idea or an action to create something that is considered new to answer common problems. According to (Makmur \& Thahier, 2015). The use of labor, both human and non-human, requires new and precise techniques so that the workforce used in the context of implementing an activity or job can provide effective and efficient results. There are many problems related to the use of labor .

According to (Wibowo, 2016) Organizational culture is a culture that is applied to a certain organizational scope that reflects the general perception of all members of the organization. Therefore, employees are required to innovate so that unwanted problems do not occur. Organizational innovation encourages individuals to think independently and creatively 
Miftahul Rahmat et.all; Correlation of Organizational... $\mid 73$

in applying personal knowledge to organizational challenges. Qualified resources, in this case employees, are the very source of determining the success of a company (Niswaty, Salam, Nasrullah, \& Pratiwi, 2017). In maintaining the company to continue to be innovative, Bulog public companies apply an organizational culture that encourages the quality of their employees, starting from hiring employees who use third parties so as to minimize fraud by certain parties in the company then giving responsibility, workload and fair rewards for each employees. According to (Tadampali, Hadi, \& Salam, 2016) the factors that need to be the company's attention are how the company manages a good and conducive work culture in employee work activities and efforts to manage human resources properly and continuously.

The relationship between organizational culture and company innovation at Perum Bulog Sulselbar Regional Division in Makassar falls into the high category. Organizational culture is closely related to company innovation, a strong organizational culture is an energy to achieve maximum employee performance which has an impact on company creativity and innovation. The results of this study are supported by an opinion (Wahdah, 2017) which states that a company that is able to use all the resources owned by the company will find it easier to generate innovation and create an appropriate innovation strategy.

\section{CONCLUSION}

Based on the research results, several conclusions will be presented, namely, based on the results of the correlation coefficient analysis, the correlation coefficient for 0.705 is obtained, so it can be concluded that there is a relationship with a high level of correlation in organizational culture variables with company innovation at Perum Bulog Regional Division of South Sulawesi in Makassar. The organizational culture in the general company Bulog, Regional Division of South Sulawesi in Makassar is in the very good category. This can be seen from the descriptive analysis, which shows that seven indicators are in the high category, namely risktaking courage, attention to detail, results orientation, human orientation, team orientation, aggressiveness and stability. The company's innovation in the general company Bulog, the Regional Division of South Sulawesi in Makassar, is in the very good category. This can be seen from the descriptive analysis, which shows that two indicators are in the high category, namely productivity and efficiency. The relationship between organizational culture and corporate innovation at the general company Bulog, Regional Division of South Sulawesi in Makassar, based on the results of the Spearman correlation analysis, it can be concluded that there is a significant relationship with a strong correlation level between organizational culture and company innovation. It is suggested that the organizational culture at Perum Bulog Sulselbar Regional Division in Makassar needs to be maintained in order to shape employee behavior at work to help company innovation. Other companies are also expected to be able to form a good organizational culture in helping companies be more innovative. 
74 Pinisi Business Administration Review

Volume 2 Number 2, September 2020. Pages 69-76

\section{BIBLIOGRAPHY}

Akib, H. (2017). Pengaruh Budaya Organisasi terhadap Kinerja Pegawai pada Dinas Pendidikan Provinsi Sulawesi Selatan. Jurnal Administrare: Jurnal Pemikiran Ilmiah dan Pendidikan Administrasi Perkantoran, 4(1), 26.

Cholliq, A. (2016). Perilaku dan Budaya Organisasi. Yogyakarta: Penerbit Ombak Tiga.

Elbru, Y. (2014). A Study On the Relationship between Organizational Culture and Organization Performance and a Model Suggestion. International Journal of Reseacrh in Business and Social Science, 3(4), 13.

Hamel, G., \& Prahalad. (2002). Competing for the future. R\&D Management, 26(2), 183-184. https://doi.org/10.1111/j.1467-9310.1996.tb00945.x

Jumrin, L. (2019). Pengaruh Budaya Organisasi Terhadap Kinerja Pegawai Pada Perusahaan Daerah Air Minum (PDAM) Kota Kendari. Journal Publicuho, 2(3).

Knapp, J. (2017). Sprint: Pecahkan Masalah-Masalah Besar dan Uji Ide-Ide Baru. Yogyakarta: PT. Bentang Pustaka.

Lamsihar, A. T., \& Huseini, M. (2019). Transformasi Budaya dan Inovasi Perusahaan BUMN. Inovbiz: Jurnal Inovasi Bisnis, 7, 64-70.

Makmur, \& Thahier, R. (2015). Inovasi dan Kreativitas Manusia. Bandung: PT. Refika Aditama.

Niswaty, R, Salam R, Nasrullah M, (2017). Motivasi Kerja Pegawai Di Kantor Keyahbandaran Utama Makassar. Jurnal Ilmiah Manajemen \& Bisnis, 18(2), 206. https://doi.org/10.30596/jimb.v18i2.1505

Pratiwi, D. A. (2019). Peran Mediasi dari Inovasi: Pembelajaran Organisasi dan Kinerja Perusahaan. Jurnal Reviu Akuntansi dan Keuangan, 9(2), 178.

Riyanto. (2019). Pengaruh Komitmen Organisasi Terhadap Kinerja Manajerial Rumah Sakit Islam Jakarta. AL-Khara: Jurnal Ekonomi, Keuangan \& Bisnis Syariah, 1(1), 45.

Robbins, S., \& Judge. (2015). Budaya Organisasi. Jakarta: Salemba.

Siyoto, S., \& Sodilk, A. (2015). Dasar Metodologi Penelitian. Yogyakarta: Literasi Media Publishing.

Sugiyono. (2013). Metode Penelitian Administrasi. Bandung: Alfabeta.

Szczepanska, K. (2014). The Importance of Organizational Culture For Innovation in The 
Miftahul Rahmat et.all; Correlation of Organizational... |75

Company. Forum Scientiae Oeconomia, 2(3), 31.

Tadampali, A. C. T., Hadi, A., \& Salam, R. (2016). Pengaruh Iklim Organisasi Terhadap Turnover Intention Melalui Kepuasan Kerja Sebagai Variabel Intervening Pada Pt Bank Sulselbar. Jurnal Ilmiah Ilmu Administrasi Publik, 6(2), 35. https://doi.org/10.26858/jiap.v6i2.2479

Undang-Undang Republik Indonesia Nomor 18 Tahun 2002 Tentang Sistem Nasional Penelitian, Pengembangan dan Penerapan Ilmu Pengetahuan dan Teknologi. (2002). Diambil dari www.kelembagaan.ristekdikti.go.id

Wahdah. (2017). Mediating Effect of Knowledge Management on Organizational Learning Culture in the Contest of Organizational Performance. Journal of Management Development, 36(7), 846. 
76 Pinisi Business Administration Review

Volume 2 Number 2, September 2020. Pages 69-76 